\title{
Design and Implementation of a Digital Campus System based on the URP platform
}

\author{
Yanhong Zhang \\ Tianhe College \\ Guangdong Polytechnic Normal University, \\ Guangzhou, Guangdong 510540
}

\author{
Yunli Cheng \\ Guangzhou Nanyang College , \\ Guangzhou, \\ Guangdong, 510980
}

\begin{abstract}
The development and construction of the university informationization has become the important means for universities to improve their management level and enhance the comprehensive competitiveness.Combining with the situation of our school, Researching an overall construction scheme of the Digital Campus System with a high level of intelligentized management and based on URP

(University Resource Planning) is proposed. It focuses on researching these two aspects: the overall framework of this system and the campus's Integrated information portal. So as to achieve the greatest degree of sharing the information and resources, realize the real integration of the information technology and curriculum and promote the change from the traditional teaching methods to the new ones, as well as realizing the purpose of improving the quality of teaching, scientific research and management
\end{abstract}

\section{Keywords- URP platform, Information Portal}

\section{I.INTRODUCTION}

In recent years, many colleges and universities have been engaged in establishing the university informatization and accumulated a wealth of practical experience. The purpose of subject research is on the basis of digital information and network, Using URP as the overall construction model of digital campus, URP is to re-examine the work of the universities in this society with highly developed information technology, whose goal is to achieve the orderly management and the efficient use of universities' resources. Ultimately, realizing the comprehensive informationization in educational process, scientific decision-making and standardized management, so as to improve the quality of teaching and the level of research and management. Digital Campus is a new kind of university mode in this new century, as well as the advanced stage of campus informatization's construction.

\section{DESIGN OF THE DigITAL CAMPUS SYSTEM}

\section{A.URP architecture}

The construction of Digital Campus in Tianhe college should analyse the university's situation as a whole, and then sorting out the relationship among the university information flow, capital flow and logistics, defining the linkages among the various departments, as well as establishing the unified information standards and application support platform, and then integrating and developing the university application system. So as to form an organic and integrated university information systems.
Digital campus architecture is a hierarchy. The wheel form (Fig. 1) is used below to indicate the level of the digital campus institutions. In Figure 1, we focus on presenting the hierarchical division of functions, where, the inner circle is the core and foundation, the outer circles are further services provided on the basis of the inner circle.

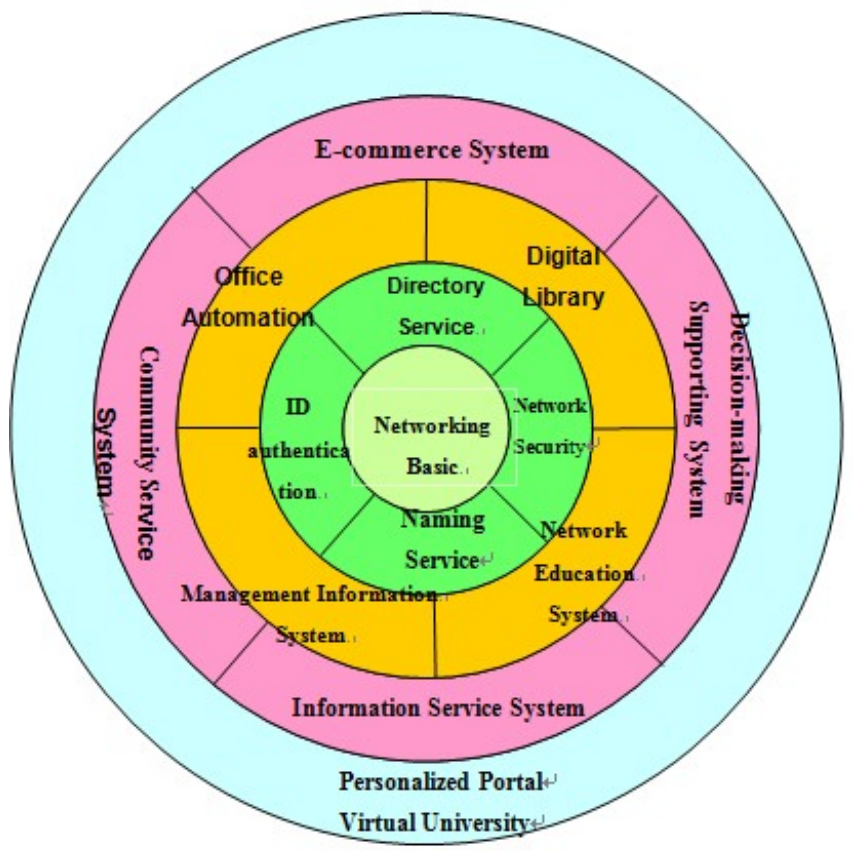

Figure 1.Digital Campus Architecture

In digital campus, it can easily complete the whole process of the school teaching, scientific research, management, services and other activities through modern means, thereby, reaching the purpose of improving the quality of teaching, scientific research and management ..

\section{B.The Model of Digital Campus System Based on URP}

Combining the specific condition of Tianhe College ,URP construction scheme was adopted in digital campus's construction, Figure 2 shows the model of digital campus system based on URP. Our focus is to indicate the division of the digital campus system modules under construction and the relationship between each module.

\section{C.Design of the Integrated Information Portal}

Integrated information portal manages and integrates the information resources and application system of 
Campus Network.For the users, the integrated information portal controls their access to information resources and application system, provides them with integrated access, customized information resources and operation data according to their different identities to satisfy their different needs, and personalized services.Integrated information portal consists of three parts, they are interface management of users, unified service of identity authentication and service of application management.

\section{III.THE IMPLEMENTATION OF THE DIGITAL CAMPUS SYSTEM}

\section{A.The basic framework of the Digital Campus Application Platform}

In order to make the URP come true, an URP system must be set up based on the information technology. Under the guidance of the advanced management theories of modern universities, it can integrate and manage all the information resources in the round, and provide the universities with a comprehensive and systematized management platform of deciding, planning, managing, operating and assessing.It not only can improve the universities' application level of IT, but also can develop the investment efficiency of hardwares to realize the real integration of IT and courses and the digitization of all kinds of resources to form a digital space,which extends the campus in time and space, to some extend, can achieve aim of improving teaching quality, scientific research level and management level.

Figure 3 shows the basic framework of a complete digital campus application platform, which is also the main architecture of the integration scheme for Tianhe College :

All parts of this frame form the" 4 horizontals and 2 longitudinals" logical relationship."4 horizontals"are correlative and infrastructure service provides a basic platform of support, where the end-users can experience all the integrated service of"application system"in the "campus portal system" by realizing the interoperability of the "application system" in the "information exchanging platform"."2 longitudinals"provides "4 horizontals"with some management ability and security of operating successfully.

\section{B. Functions 'Implementation of the Integrated Information Portal system in Campus}

In order to make the management and exchange more convenient, the basic way of the portal information system is to establish an integrated information portal by using the Sharepoint Portal Server of Microsoft Corporation. It not only can integrate the existing application information and data, but also can provide a platform for the future applications and data to emerge uniformly. The followings are some of its functions.

\section{a)Its Web-based Ability of Emerging}

With the Web-based interface, users can access to all the applications and data in the portal,including managing and customizing their own interface as long as their client has the IE browser,such as browsing students' information in IE browser.

\section{b)Sharing knowledge in campus}

It becomes easier to help the staff and students to publish their content in portal site.Teachers can integrate their Sharepoints into the ones of teaching and research group, which makes them to share their knowledge with the teachers of other grades. They can publish their documents and best practices in the public view of their own individual site for others to use them.

\section{c)Personalized customizations.}

With the digital dashboard, users can custom the appearance and content of their accessing interface, including typeface, color, style and different contents according to different needs of the users. They can custom by way of pulling, drawing and dragging via the web-based management interface. In addition, different contents will be showed due to different users and their different levels.

\section{d)Application functions of the integrated information portal}

The typical application system in campus consists of five major parts, it provides different functions for school leaders, teachers, students, parents, and system administrators respectively.

\section{IV.CONCLUSION}

This paper conducts a deep research on the digital campus system based on URP platform, the utilization of URP as the overall construction model of digital campus is proposed, it can realize the real integration of information technology with curriculum, and promote the transformation from the traditional teaching methods to the new ones, the solution of the campus application platform can be applied and achieved in this system. Due to the limitation of the research standards and research time, the subject is slightly weak in the Design and implementation of digital campus system based on URP platform, there are still many problems should continue to improve and explore.

\section{REFERENCES}

[1] Gupbao Zhang, Zhenghe Liang, and Xinhua, Zhang. Construction of the Digital Campus Patform . Beijing: China Education Press, 2007

[2] T. J. Schorn. Management Purpose and Audit System Design. Transactions of the American Foundry Society, 2005

[3] Yuexiong He.Teaching and Construction Management Platform of Support in Huzhou Normal College[D];East China Normal University,2010.

[4] Jain, A. K. Biometric-based personal identity-authentication system and security analysis. Proceedings of the IEEE, 2006

[5] Jiayuan SHi, Lei Tang. Design and Implementation of Unified Digital Campus Portal in Universities.Computer Engineering and Design,2007

[6] Shangsen Yang,Unified Authentication of Identity and Its Application in Campus Web. Journal of Luoyang University.2006

[7] Xiaodong Pi. Research and Implementation of Single Sign-On. Computer Application and Softwares, 2007

[8] Xin Xu, Xinning Su, Jiong Lu. Design of Identity-Authentication system of Digital Campus. Modern Library and Information Technology,2005 
[9] Binghui Qi.Research and Application of Building the RIA System

Based on Flex.Donghua University,2010

\begin{tabular}{|c|c|c|c|c|c|c|}
\hline \multirow{6}{*}{$\underset{⿱ 乛}{\Xi}$} & \multicolumn{5}{|c|}{$\begin{array}{l}\text { URP Portal } \\
\text { (Application Aggregation Emerging. Personal desktop Customization. Single Sign-On Roaming etc) }\end{array}$} & \multirow{6}{*}{ 焉 } \\
\hline & \multicolumn{5}{|c|}{ URP Applications } & \\
\hline & $\begin{array}{c}\text { Management } \\
\text { Information System. } \\
\text { Teaching Affairs } \\
\text { Scientific Research } \\
\text { Financial Affairs } \\
\text { Human Resources } \\
\text { Equipment Asset } \\
\text { Files } \\
\text {................ }\end{array}$ & $\begin{array}{c}\text { i-office System. } \\
\text { Official Business. } \\
\text { Documents: } \\
\text { Space. }\end{array}$ & $\begin{array}{c}\text { Digital Library. } \\
\text { Periodicals.। } \\
\text { Bools: } \\
\text { Paper Database. }\end{array}$ & $\begin{array}{c}\text { Network } \\
\text { Teaching } \\
\text { Materials } \\
\text { Courseware } \\
\text { Item Bank } \\
\text { Platform: } \\
\text {............. }\end{array}$ & $\begin{array}{c}\text { Web Services.। } \\
\text { E-mail.. } \\
\text { information } \\
\text { publishing.ı } \\
\text { IP Telephone. } \\
\text { Video Conference:I } \\
\text { Community Service.. } \\
\text { Decision Support.. } \\
\text {............... }\end{array}$ & \\
\hline & Application Managen & ent, User's manager & $\begin{array}{l}\text { RP Platform } \\
\text { ent and certificatio }\end{array}$ & Rights Mans & ent,Data Exchange & \\
\hline & CNetvorkManagement & $\begin{array}{r}\text { Applicati } \\
\text { System. Target Service }\end{array}$ & $\begin{array}{l}\text { n supporting } \\
\text { ystem. Domain Name }\end{array}$ & $\begin{array}{l}\text { stem } \\
\text { nice System. } 0\end{array}$ & e Paymeut System etc) & \\
\hline & & $\begin{array}{r}\text { Hard } \\
\text { mputer System. }\end{array}$ & $\begin{array}{l}\text { are Infrastruct } \\
\text { ampus Network. }\end{array}$ & Data Center & & \\
\hline
\end{tabular}

Figure 2.Model of Digital Campus System Based on URP

\begin{tabular}{|c|c|c|c|c|c|c|c|}
\hline \multirow[b]{2}{*}{ 品 } & \multicolumn{6}{|c|}{$\begin{array}{l}\text { Integrated Information Portal System in Campus } \\
\text { Providing the Integrated ,Personalized And Customized Comprehensive } \\
\text { Information Service Portal }\end{array}$} & \multirow{6}{*}{ 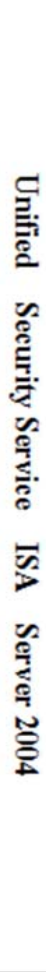 } \\
\hline & $\begin{array}{l}\text { Teaching } \\
\text { Resources }\end{array}$ & $\begin{array}{l}\text { Teaching } \\
\text { Display } \\
\text { System }\end{array}$ & $\begin{array}{l}\text { Interactive } \\
\text { Teaching } \\
\text { System }\end{array}$ & $\begin{array}{c}\text { Teaching } \\
\text { Evaluation } \\
\text { System }\end{array}$ & $\begin{array}{c}\text { Teaching } \\
\text { Management } \\
\text { System }\end{array}$ & $\begin{array}{c}\text { School } \\
\text { Management } \\
\text { System }\end{array}$ & \\
\hline 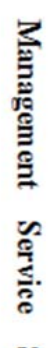 & $\begin{array}{c}\text { Courseware } \\
\text { Designing } \\
\text { E-Activity } \\
\text { Resource } \\
\text { Storage } \\
\text {................ }\end{array}$ & $\begin{array}{c}\text { E-classroom } \\
\text { Web page } \\
\ldots \ldots \ldots \ldots . . . . . . . . .\end{array}$ & $\begin{array}{c}\text { classroom } \\
\text { interaction } \\
\text { online } \\
\text { answer } \\
\text { Offline } \\
\text { guidance } \\
\text { System of th }\end{array}$ & $\begin{array}{c}\text { online } \\
\text { examination } \\
\text { Progress } \\
\text { evaluation } \\
\text { Education In }\end{array}$ & $\begin{array}{c}\text { Students' } \\
\text { information } \\
\text { system } \\
\text { Teachers' } \\
\text { information } \\
\text { system } \\
\text { course } \\
\text { schedule } \\
\text { formationization }\end{array}$ & $\begin{array}{c}\text { assets } \\
\text { management } \\
\text { files } \\
\text { management } \\
\text { campus } \\
\text { e-card }\end{array}$ & \\
\hline$\sum_{3}^{3}$ & \multicolumn{6}{|c|}{$\begin{array}{l}\text { Platform of Application Integration and the Unified Information Exchange: } \\
\text { BizTalk Server } 2004\end{array}$} & \\
\hline & \multicolumn{6}{|c|}{ Basic Framework Service } & \\
\hline & $\begin{array}{r}\text { Unif } \\
\text { Mana } \\
\text { Windows }\end{array}$ & $\begin{array}{l}\text { d ID } \\
\text { ement } \\
\text { erver } 2003\end{array}$ & $\begin{array}{l}\text { Unified D: } \\
\text { SQL Ser }\end{array}$ & $\begin{array}{l}\text { ta Service } \\
\text { ver } 2000\end{array}$ & $\begin{array}{r}\text { Collaborat } \\
\text { Enviro } \\
\text { Exchange 2003 }\end{array}$ & $\begin{array}{l}\text { tive Work } \\
\text { nment } \\
3 \text { \& LCS } 2003\end{array}$ & \\
\hline
\end{tabular}

Figure 3.The basic framework of the integration program in Tianhe College 